\title{
Macrobenthic colonisation of disturbances on an intertidal sandflat: the influence of season and buried algae
}

\author{
R. B. Ford ${ }^{1, *}$, S. F. Thrush ${ }^{2}$, P. K. Probert ${ }^{1}$ \\ ${ }^{1}$ Department of Marine Science, University of Otago, PO Box 56, Dunedin, New Zealand \\ ${ }^{2}$ National Institute of Water and Atmospheric Research Ltd, PO Box 11-115, Hamilton, New Zealand
}

\begin{abstract}
This study examines whether macrofaunal colonisation differs seasonally in an intertidal sandflat. Frozen cores were placed in the sandflat within each season and colonisation of these cores was followed for $50 \mathrm{~d}$. This study shows a previously untested effect of buried algal mats on colonisation. A change in the sediment organic content can increase or decrease macrofaunal densities. Community colonisation rates of defaunated plugs were slower in winter compared to summer because of the higher numbers of rare macrofauna in winter. Community colonisation of plugs with algal additions were also dependent on the seasonally varying response of the corophiid amphipod Paracorophium excavatum, the most abundant species in this community. The strongest effect of the experiments was linked to critical densities of $P$. excavatum, irrespective of season. A mechanism for this linkage is suggested. This study also emphasises the importance of post-settlement movement as the mechanism by which most species on this sandflat colonised in either season.
\end{abstract}

KEY WORDS: Intertidal sands - New Zealand B Buried algae - Colonisation · Community ecology Paracorophium excavatum Seasonal effects

\section{INTRODUCTION}

Disturbance events are a major source of temporal and spatial heterogeneity structuring natural communities (Sousa 1984). Disturbance creates an opportunity for new individuals (or colonies) to become established (Sousa 1984). These opportunities are an important basis of the 'temporal and spatial mosaic of patches' (Johnson 1973) that characterise the distribution of soft sediment infaunal organisms. The age-structure of recovering communities after disturbances can be influenced by different modes of colonisation transporting specific life-history stages (Shull 1997).

Colonisation mechanisms in marine soft-bottom habitats include larval settlement, burrowing, and post-larval movement through erosion or swimming (Shull 1997). Determining the relative importance of

\footnotetext{
- Present address: Gatty Marine Laboratory, University of St. Andrews Fife, KY16 8LB, Scotland, UK

E-mail: rbf1@st-and.ac.uk
}

colonisation mechanisms used by infaunal species is critical for predicting changes in benthic communities following a disturbance (Santos \& Simon 1980, Levin 1984, Smith \& Brumsickle 1989, Shull 1997). Postlarval settlement has been demonstrated for mudflats (Beukema 1973, Thrush \& Roper 1988, Frid 1989, Gunther 1992), but it is usually assumed that post-larvae will be important recolonisers only over small scales, for example, $50 \mathrm{~cm}^{2}$ (Smith \& Brumsickle 1989). For sandflats, in contrast, many post-larvae are transported over larger distances in the sediment bedload (Olivier et al. 1996, Shull 1997) and via active dispersal (Beukema 1973, Cummings et al. 1993). Sediment bedload is strongly correlated with wind-wave induced sediment disturbance (Emerson 1991, Commito et al. 1995b). This correlation occurs as the turbulence generated by wind-waves often suspends sediment, which tidal currents then transport (Bell et al. 1997).

Bedload movement is an important transport mechanism for recolonisers, especially for sandflats. In intertidal or shallow sites, several studies have demon- 
strated colonisation can be seasonally affected (Zajac \& Whitlatch 1982a, Beukema \& De Vlas 1989, DiazCasteñada et al. 1993). Wind has been identified as the causative agent in seasonal differences in colonisation for only one of these cases (Beukema \& De Vlas 1989).

Seasonality in colonisation can be controlled by at least 2 other possibly interacting factors: numbers of colonisers and mode of colonisation. In spring and summer, high numbers of colonists allowed high rates of colonisation in response to disturbance events in a Connecticut estuary (Zajac \& Whitlatch 1982a), whilst another study showed low abundances of Gemma gemma slowed colonisation in winter (Commito et al. 1995a). Other studies have shown winter colonisation to be dominated by post-larval stages in comparison to other seasons (Beukema \& De Vlas 1989, DiazCasteñada et al. 1993).

Algal mats settling on sandflats are a result of coastal eutrophication, a large and increasingly important global marine problem (GESAMP et al. 1990). Initially, these mats may cause macrofaunal densities to increase because of an increased food resource, but under dense algal mats the sediment becomes anoxic and densities of macrofauna in intertidal areas decrease (Hull 1987, Tufail et al. 1989). Sediment deposition often causes these mats to become buried. Although the ecological effects of surface algal mats are comparatively well studied (Nicholls et al. 1981, Thrush 1986, Hull 1987, Raffaelli et al. 1989, Peterson et al. 1994, Norkko \& Bonsdorff 1996, Norkko 1997), the effects of buried algal mats on macrofauna have received only incidental documentation (Hull 1987). Buried algal mats may influence sediment colonisation after surface algal mats decay, changing the densities of macrofauna and therefore their susceptibility to the next disturbance event. Algal disturbances may also have secondary impacts on macrofaunal consumers, including the decline of birds and commercially important fish species (Nicholls et al. 1981).

A manipulative field experment was designed to test the null hypothesis that there is no difference in colonisation by macrofauna of sediments with algal enrichment, between seasons or within seasons. Wind and modes of colonisation were also monitored to provide information on probable mechanisms for any differences seen in colonisation rates. To our knowledge, this is the first study, to explicitly investigate the effect of buried algal mats and time of season upon colonisation in an intertidal sandflat.

\section{METHODS}

Location. This study was located on the high intertidal sandflats of Papanui Inlet, Otago Peninsula, New Zealand $\left(45^{\circ} 52^{\prime} \mathrm{S}, 170^{\circ} 42^{\prime} \mathrm{E}\right.$ ). Papanui Inlet is $3.5 \mathrm{~km}^{2}$ in area, exposed to the dominant southerly wind and experiences a spring tidal range of $\sim 2 \mathrm{~m}$. Sediments consist of fine sand (mean particle $=172$ to $174 \mu \mathrm{m}$ ). Sediment total organic content was $0.63 \%$ of sediment dry weight. The study site ( 30 by $30 \mathrm{~m}$ square) was immersed for $4 \mathrm{~h}$ and 40 min to a maximum depth of $33 \mathrm{~cm}$ and experienced tidal currents up to $17 \mathrm{~cm} \mathrm{~s}^{-1}$ on a spring tide on February 7, 1998. This site supports a soft sediment macrofaunal community that is numerically dominated by the corophiid amphipod Paracorophium excavatum.

Experimental design. Experiments were conducted in the summer of $1994 / 95$ and the winter of 1995 (Fig. 1). On 6 occasions, 3 in summer ( $51=4 / 12 / 94$, $\mathrm{S} 2=5 / 1 / 95, \mathrm{~S} 3=4 / 2 / 95)$, and 3 in winter ( $\mathrm{W} 1=1 / 6 / 95$, $\mathrm{W} 2=1 / 7 / 95, \mathrm{~W} 3=1 / 8 / 95), 50$ sediment plugs (cores $20 \mathrm{~cm}$ diam. $\times 10 \mathrm{~cm}$ deep) were extracted near the study site. The following day, 25 defaunated (D) and 25 algal addition (A) plugs were transplanted upright and flushed with the ambient sediment at random locations within the study site. To test the hypothesis that buried algal mats in sandflats would influence macrobenthic recovery, 3 experimental treatments were used, defaunated (D), algal additions (A) and controls (C), D and A treatments consisted of sediment plugs (cores $20 \mathrm{~cm}$ diam. $\times 10 \mathrm{~cm}$ deep), which were frozen $\left(-18^{\circ} \mathrm{C}\right)$ for at least $12 \mathrm{~h}$ to kill all macrofauna. To mimic the organic enrichment effect of a buried macroalgae mat, a $1 \mathrm{~cm}$ deep layer of frozen Ulva sp. (Chlorophyta) was

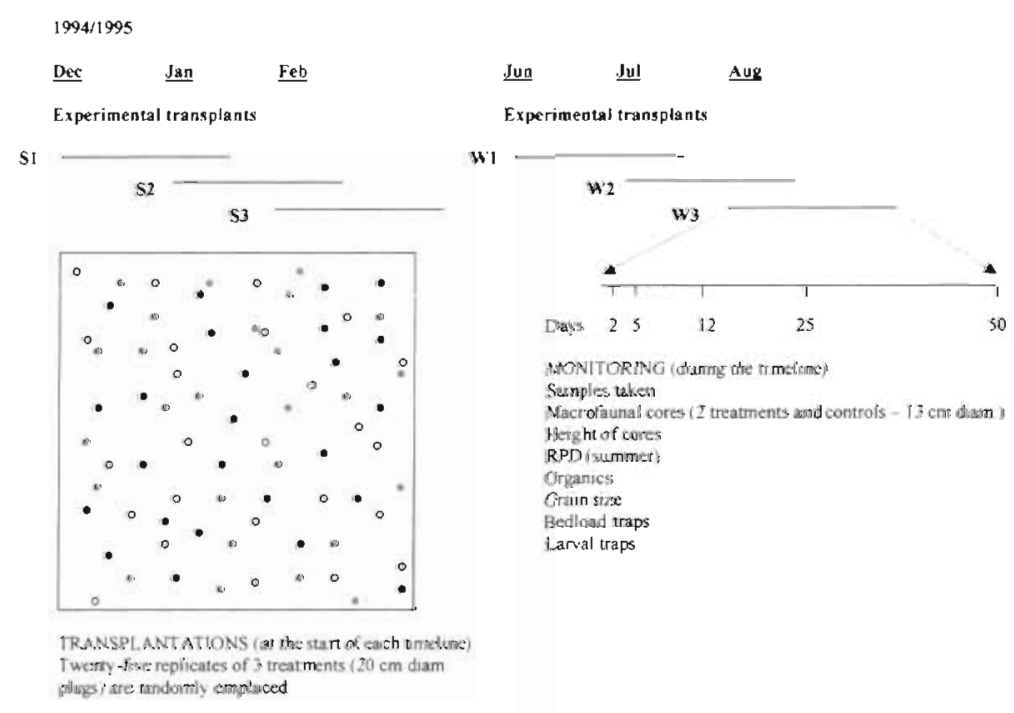

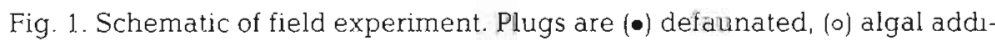
tion and ( $\bullet$ controls 
inserted in the plug at a depth of 2 to $3 \mathrm{~cm}$; this treatment was referred to as $\mathrm{A}$. Personal observations over $50 \mathrm{~d}$ confirmed the presence of the algae within the sediment in increasingly smaller fragments. C treatments were taken at random positions within the unaltered experimental site. Plugs were transplanted on 3 occasions at monthly intervals within each season, to coincide with spring tides.

Around each plug a PVC band $(20 \mathrm{~cm}$ diam. $\times 1 \mathrm{~cm}$ wide) was buried 2 to $3 \mathrm{~cm}$ below the sediment surface. To relocate plugs, the correct co-ordinates were located, and then a wire stake was used to probe for the PVC band that marked each plug. The bands were placed at this depth on the assumption that they would cause little interference with lateral movement of animals, as there were lower densities of organisms at this depth. Subsequent in situ tests of the effect of bands and coring on colonisation were completed in late summer. No significant difference was seen in any taxon identified by SIMPER as causing differences in later analyses. Therefore, artefacts associated with experimental transplantation were considered negligible in this study

An integrated sampling programme was followed at $2,5,12,25$ and $50 \mathrm{~d}$ following each transplantation (Fig. 1). On each occasion, 5 macrofaunal cores $(13 \mathrm{~cm}$ diam. $\times 10 \mathrm{~cm}$ deep) were taken from the middle of 5 plugs of each treatment, e.g. algal enriched, control and defaunated. All macrofaunal samples were sieved through $500 \mu \mathrm{m}$ mesh. The residues from sieving were preserved in $10 \%$ formalin and $0.1 \%$ rose bengal in seawater for later sorting and identification.

Before coring, the height of each location was measured with a theodolite (against the height of a reference stake), to test that transplants were flush with the bed and not causing flow disturbance effects.

Average wind speed was monitored at a nearby weather recording station (Taiaroa Heads: $45^{\circ} 46^{\prime} 30^{\prime \prime} \mathrm{S}$, $170^{\circ} 42^{\prime} 30^{\prime \prime} \mathrm{E}$ ) at $3 \mathrm{~h}$ intervals for the duration of the experiment.

Redox Potential Discontinuity (RPD) depths were measured in winter to test for an effect of treatments, as observations in summer showed that the depth of the oxic layer appeared to differ with treatment. The depth of the apparent RPD is a quick indicator of sediment oxygen levels (Pearson \& Stanley 1979). RPD depths varied within each core, therefore 3 RPD depth measurements were taken at $120^{\circ}$ steps around the core and averaged.

Bedload traps and larval traps were deployed, 1 at each of the 4 corners of the study site to try and identify if modes of colonisation differed. Bedload traps consisted of tin foil trays $(17 \times 13 \times 5 \mathrm{~cm})$ filled with frozen $\left(-18^{\circ} \mathrm{C}\right.$ for $>12$ h) ambient sediment (Grant 1985). Larval traps consisted of over-collecting shaped bottles (Butman et al. 1986) $26 \mathrm{~cm}$ high with $24 \mathrm{~mm}$ diameter openings, vertically fixed to a stake so that the bottle opening was $25 \mathrm{~cm}$ above the sediment. Traps were collected and replaced at times of tidal emmersion on monitoring days. All trap samples were preserved in the same way as macrofaunal samples. Larval and bedload traps were analysed for presence/absence of macrofauna only.

This sampling programme is detailed in Fig. 1. The exception to this monitoring programme was Summer Transplant 2, Day 25 (S2D25) when the sampling was missed.

Statistical anaiyses. Datd were analysed using a combination of multivariate and univariate techniques. Multivariate techniques were used to gauge community response, then univariate techniques were used to study those taxa highlighted as strongly contributing to community level effects.

The Plymouth Routines in Multivariate Ecological Research (PRIMER) software package (Clarke \& Warwick 1994) was used to create Bray-Curtis similarity matrices of taxa counts. Given the large numerical dominance of a few species, a 4th root transformation was applied to the data; this reduces the effect of dominant taxa and differentiates between samples with many and few rare taxa (Clarke \& Green 1988). Similarity matrices were then subjected to a number of analyses. Matrices first underwent cluster and Multidimensional Scaling (MDS) ordination analyses (Field et al. 1982). Stress values, which indicate the extent to which the similarities are preserved in the 2-D map, are presented for all MDS. The smaller the stress values the better; ordinations with stresses lower than 0.2 are 'useable' although little reliance should be placed on the fine details of the plot when stress values are between 0.1 and 0.2 (Clarke 1993).

One-way ANOSIM was used to test for significant differences between seasons, treatments or replicates (Clarke \& Green 1988, Clarke 1993). The Multivariate Dispersion (MVDISP) package measures relative dispersion; samples that are more dispersed (have higher values) at the same time are considered to be more stressed (Lambshead \& Gooday 1990, Warwick \& Clarke 1993, Lambshead \& Hodda 1994). Taxa that strongly affected groupings were identified (after ANOSIM) by a ratio generated by the SIMPER procedure (Clarke 1993). The ratio consisted of the average contribution to similarity or dissimilarity of the taxon versus the standard deviation of the taxon. A value of this ratio greater than 1.4 indicates a consistent discriminating taxon (Clarke 1993, Clarke \& Warwick 1994). As SIMPER has a program limit of 30 samples, average values for each transplant/day/treatment combination, (i.e. W1/D2/C, W1/D2/A, W1/D2/D, W1/D5/C, etc.j were used for some analyses. 
ANOVA and LSD post hoc tests were used to test for effects in univariate macrofaunal data. Season, treatment, time of transplantation and all interactions between these factors were tested. Amphipods and some bivalves showed clear size variation, and possibly variation in movement with age. Therefore, they were split into adult (amphipod $>3 \mathrm{~mm}$, bivalves $>10 \mathrm{~mm}$ ) and juvenile size classes. Transformed counts $(\log +1)$ of the 2 numerically dominant species (Paracorophium excavatum adults and juveniles and Perrierina turneri), number of individuals and number of taxa were all analysed using the same ANOVA model. P-values were tabulated, and when comparisons were made from a number of $p$ values in a table the Type I error $(\alpha=0.05)$ was adjusted using the sequential Bonferroni technique to indicate significance (Holm 1979, Rice 1989). Other taxa of good discriminating power, as indicated by multivariate SIMPER analysis, but of low abundance $k 1$ per control core) were transformed (square root +0.5 ) and analysed using a single-factor ANOVA for the relevant affect.

Raw height data was tested for homogeneity of variance (Cochran's test) and normality (Shapiro-Wilks test). Height data for all cores within the site were first examined for covariance with 2 horizontal spatial coordinates $x, y$ and $x \times y$. Significant effects showed a significant slope within the site, at that time. To determine if the 2 manipulated treatments differed from the control, the appropriate treatment interaction was then selected and tested for significance. For example, if $x$ was significant then Treat $x x$ was tested for signifi- cance. If no covariance was shown treatment effects were tested on the raw data.

Wind data were analysed for difference between seasons using a chi-squared analysis of frequency. Frequencies strongly contributing to significant differences were isolated by examination of residuals (Haberman 1973, Grant \& Tyler 1983).

\section{RESULTS}

\section{Control community}

ANOSIM and MDS ordination from each sampling time clearly separated summer and winter control sites $(p=0.001)$, although the average dissimilarity between seasons was small $(23 \%)$. Thirty-seven taxa were identified, but the lyamiacid bivalve Perrierina (Legrandia) turneri and the corophiid amphipod Paracorophium excavatum constituted at least $88 \%$ of all individuals at the start of each transplantation. ANOVA on seasons showed that $P$. excavatum adults and juveniles, number of individuals and number of taxa were all significantly more abundant in winter than summer (Table 1, Fig. 2a,b,d,e), whereas $P$. turneri was significantly more abundant in summer than winter (Table 1 , Fig. 2c). Rare species (<1 per control core) identified by SIMPER as being consistent contributors to the difference in season were the spionid polychaetes Scololepides benhami and Boccardia syrtis and the phoxocephalid amphipod Torridoharpinia hurleyi. These 3 rare species had significantly higher densities in winter (all $\mathrm{df}=1 / 148, \mathrm{p} \leq 0.0001$ ). Within season trends also existed. Total number of individuals at the site increased through summer and decreased through winter, this trend was mainly caused by the trend in juvenile P. excavatum (Figs, 2b,e \& 3).
Fig. 2. Control abundance per core for the 2 most common species and 2 group indicators. Transplant 1 (匹). Transplant 2 (ם), Transplant 3 (\%). $S:$ summer and $W$ : sinter, \pm 1 standard error

\begin{tabular}{|c|c|c|c|c|c|}
\hline \multirow[b]{2}{*}{ Factor } & \multicolumn{5}{|c|}{ ANOVA } \\
\hline & $\begin{array}{l}\text { Paracorophium } \\
\text { excavatum } \\
\text { juveniles }\end{array}$ & $\begin{array}{c}\text { Paracorophium } \\
\text { excavatum } \\
\text { adults }\end{array}$ & $\begin{array}{l}\text { Pernienna } \\
\text { turneri }\end{array}$ & $\begin{array}{l}\text { No. of } \\
\text { indi- } \\
\text { viduals }\end{array}$ & $\begin{array}{c}\text { No. of } \\
\text { taxa }\end{array}$ \\
\hline Treatment $(\mathrm{T})$ & $\leq 0.001$ & $\leqq 0.001$ & $\leqq 0.001$ & $\leq 0.001$ & $\leq 0.001$ \\
\hline Season (S) & $\leq 0.001$ & $\leqq 0.001$ & 0.003 & $\leqq 0.001$ & $\leqq 0.001$ \\
\hline Transplant (P) & 0.001 & 0.0296 & $\leqq 0.001$ & $\leq 0.001$ & $\leq 0,001$ \\
\hline $\mathrm{T} \times \mathrm{S}$ & 0.002 & $\leq 0.001$ & 0.167 & 0.008 & 0.940 \\
\hline $\mathrm{S} \times \mathrm{P}$ & $\leqq 0.001$ & $\leqq 0.001$ & $\leqq 0.001$ & $\leqq 0.001$ & $\underline{0.002}$ \\
\hline
\end{tabular}




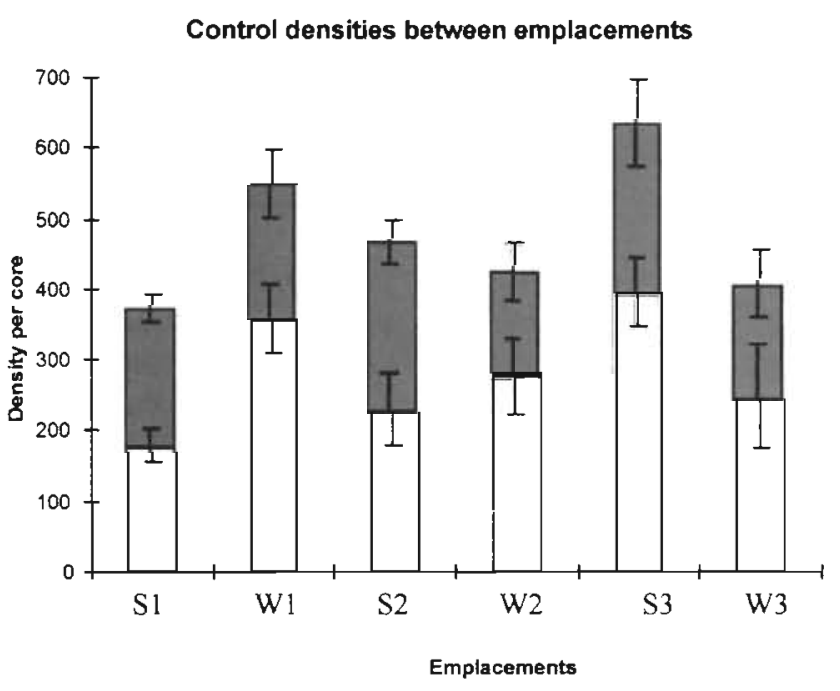

Fig. 3. Number of individuals and numbers of Paracorophium excavatum in control cores in different seasons and transplants. Number of individuals ( $\square$ ), number of $P$. excavatum ( $\square$ ). \pm 1 standard error

\section{Difference in recovery with treatment and season}

Multivariate tests were used to look for any difference in colonisation with treatment at each seperate time e.g. Summer Day 2, Winter Day 25. All times showed significant treatment effects. Pairwise comparisons showed abundances in control samples were significantly greater than abundances in algal and defaunated samples on all days except one (SD5, $\mathrm{df}=2 / 14, \mathrm{p}=0.09$ ). When the algal treatment was compared to defaunated treatments, a pattern was seen that differed with season. In summer, significant differences between algal and defaunated treatments were seen at Days 2 and $5(\mathrm{df}=4 / 12, \mathrm{p}=3.3$ and 0.4 respectively). In winter, significant differences were seen between algal and defaunated treatments at Days 5, 12 and $50(\mathrm{df}=4 / 12, \mathrm{p}=0.0,0.6$ and 4.1 respectively). This contrast between seasons was clearest at Day 2. At Day 2, treatment effects were clear in summer ( $\mathrm{df}=4 / 12, \mathrm{p}=3.3$ ), but in winter algal and defaunated sample areas overlap (df = $4 / 12, p=99.0$ ) (Fig. 4). The order of this trend was reversed as sampling day increased. Relative dispersion values showed control samples to be less variable than the other 2 treatments (Table 2). In 6 out of 10 cases, algal treatments were the most variable. Juvenile and adult Paracorophium excavatum were the only species seen by SIMPER to show a consistent difference on more than 1 sampling day. Taxa that showed consistent differences between more than 1 pair of treatments on 1 day were Perrierina

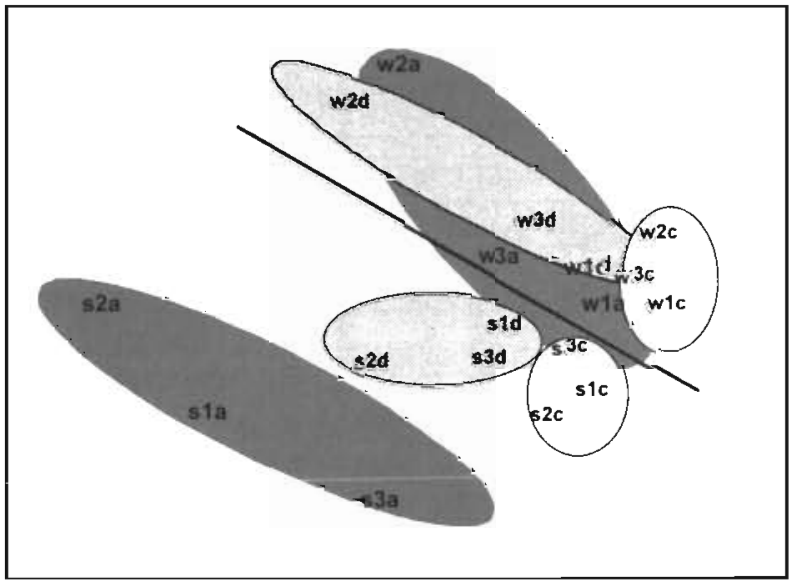

Fig. 4. MDS ordination plot of Day 2 average samples, (stress $=0.18$ ). Labeled by season ( $\mathrm{S}$ : summer, $\mathrm{W}$ : winter), transplantation $(1,2$ or 3 ) and treatment $(\mathrm{b}=$ control, $\mathrm{a}=$ algal addition and $d$ = defaunated). Samples within elipses (drawn by eye to indicate groupings) are control samples ( $\square$ ), defaunated samples ( $m$ ), or algal addition samples $(\boldsymbol{m})$. The bold line separates the seasons

turneri (D5), juvenile Austrovenus stutchburyi (D12), Edwardsia sp. (D25) and adult Torridoharpinia hurleyi (D50).

Experimental treatments had a clear effect on recovery times. Recovery is defined here as when the mean of the algal or defaunated treatment falls within the $95 \%$ confidence interval of the control treatments mean for the second time. The second time was chosen for recovery as this safeguards against sudden control densities decreases. Number of taxa took longer to recover than other indicators, only the defaunated treatment showed any recovery inside $50 \mathrm{~d}$ (Fig. 5). Paracorophium excavatum adults and juveniles generally recovered more quickly in winter than summer in both treatments (Fig. 5). Algal treatments showed significantly more adult ( $d f=2 / 14, p<0.0001)$ and juve-

Table 2. Relative dispersion values for control (C), algal additions (A) and defaunated (D) treatments. Relative dispersion values are comparable between treatments on the same day

\begin{tabular}{|lccc|}
\hline $\begin{array}{l}\text { Sampling } \\
\text { day }\end{array}$ & C & Relative dispersion \\
\hline S Day 2 & 0.72 & 1.23 & D \\
S Day 5 & 0.69 & 1.34 & 1.14 \\
S Day 12 & 0.75 & 1.15 & 1.13 \\
S Day 25 & 0.81 & 1.21 & 1.11 \\
S Day 50 & 1.17 & 1.07 & 1.07 \\
W Day 2 & 0.59 & 1.27 & 1.01 \\
W Day 5 & 0.50 & 0.69 & 0.92 \\
W Day 12 & 0.75 & 1.36 & 0.95 \\
W Day 25 & 0.63 & 1.22 & 1.11 \\
W Day 50 & 0.80 & 0.82 & 1.07 \\
\hline
\end{tabular}


Algal treatment recovery times

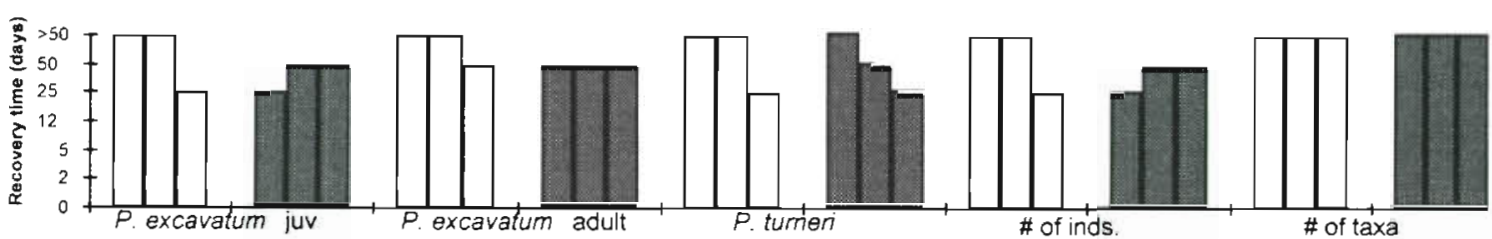

Defaunated treatment recovery times

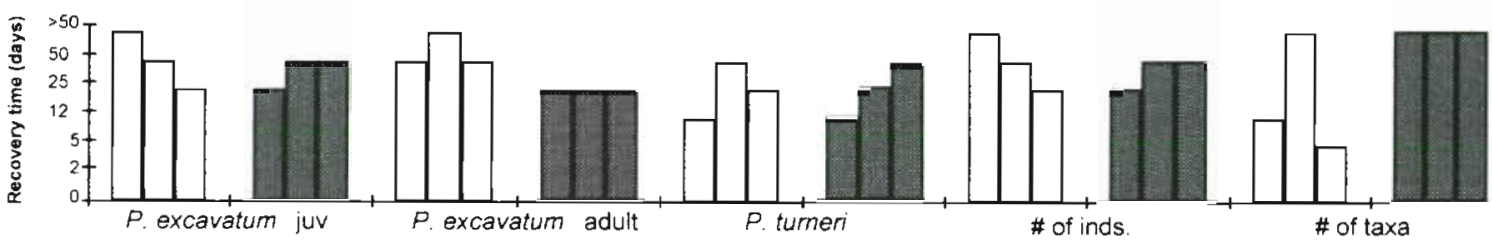

Fig. 5. Recovery times for algal and defaunated treatments. (四) summer, (ㅁ) winter (bars for each season and parameter indicate Transplants 1, 2 and 3)

nile $P$. excavatum ( $\mathrm{df}=2 / 14, \mathrm{p}<0.0001$ ) at Day 50 than control or defaunated treatments in winter, but not summer ( $\mathrm{df}=2 / 14, \mathrm{p}=0.183$ ). This instance was the only time where $A$ or $D$ significantly exceeded $C$ for any factor tested. Taxa identified by SIMPER as consistently important for differentiating between treatments were Perrierina turneri (D5), juvenile Austrovenus stutchburyi (D12), Edwardsia sp. (D25) and adult Torridoharpinia hurleyi (D50). All these taxa showed significant differences to be one of the order $C>A>D$.

\section{Difference in recovery with transplantation}

To test the hypothesis that colonisation does not change within season, recovery paths were plotted on MDS ordinations. The distance a recovery path starts from the control region, the length of the path, and the directness of the to the control region, can all be used as indicators of recovery. These indicators respectively show the magnitude of the initial impact, how long recovery takes to occur, and how erratic the recovery was. When average recovery paths are viewed for the different transplant and treatment combinations within seasons (Figs. 6 \& 7), all treatments had the greatest impact at S2 (January) and W2 (July). SIMPER shows that Paracorophium excavatum was consistently the most important taxa for distinguishing differences between transplants.

A possible mechanism for the similarity between S2 and $W 2$ is the similarity in numbers of organisms between these 2 times. ANOVA on numbers of individuals per core between transplants showed no significant difference for S2 versus W2 ( $p=0.74)$. The aver- age numbers of individuals per core for W2 (430) and S2 (427) were nearly identical (Fig. 3). Paracorophium excavatum numbers are the main cause of this trend in number of individuals, as numbers per core are 278 at W2 and 275 at $\mathrm{S} 2$ respectively (Fig. 3).

\section{Physical factors}

Physical factors were analysed to look for possible causes of the differences seen in the above results. Chi-squared analysis of wind speed showed the average seasonal wind strength was significantly stronger in winter $\left(\bar{x}=9.27 \mathrm{~m} \mathrm{~s}^{-1}, \sigma=5.26\right)$ than summer $\left(\bar{x}=7.61 \mathrm{~m} \mathrm{~s}^{-1}, \sigma=5.28\right)(\mathrm{p}=0.004)$. This difference was mainly due to 2 wind frequencies: the greater number of low wind speed days $\left(0\right.$ to $\left.5 \mathrm{~m} \mathrm{~s}^{-1}\right)$ in summer compared to winter and the greater number of winter days with wind speeds of 10 to $15 \mathrm{~m} \mathrm{~s}^{-1}$ (Fig. 8). Strong winds produce waves and could cause erosion and/or mortality on intertidal flats. A sharp drop in number of taxa and number of individuals did occur in all 3 treatments between Days 2 and 5 of the third winter transplantation. This was the only time when a disturbance was thought to have affected the whole site. However, wind speed alone is not considered responsible for this disturbance. Throughout this time wind speed did not exceed $14.4 \mathrm{~m} \mathrm{~s}^{-1}$, and tides were up to $2.2 \mathrm{~m}$ in range. The greater water depth over the site, and therefore possibly larger wind-waves and elevated tidal currents at this time may, however, be responsible for this effect.

All common species were recorded in bedload traps in similar numbers in both seasons. This indicates that these organisms were recolonising by post-settlement 
movement or larval transport. Infauna were not consistently found in larval traps. Not all rare species were present in bedload traps, but of those rare taxa considered by SIMPER as important in structuring the community, only Scololepides benhami was missing from bedload traps.

The effect of treatment on depth of RPD was variable, and unpredictable with time. On 5 of 15 sampling occasions in winter there was a significant difference in RPD depth with treatment (Table 3). On all of these occasions, $C$ had the greatest RPD depth. Significant differences were concentrated at Days 25 and 50 of Transplants 1 and 2.

Analyses showed no effects of treatment on bed height and only spurious correlations between bed height and wind speed. Theodolite measurements
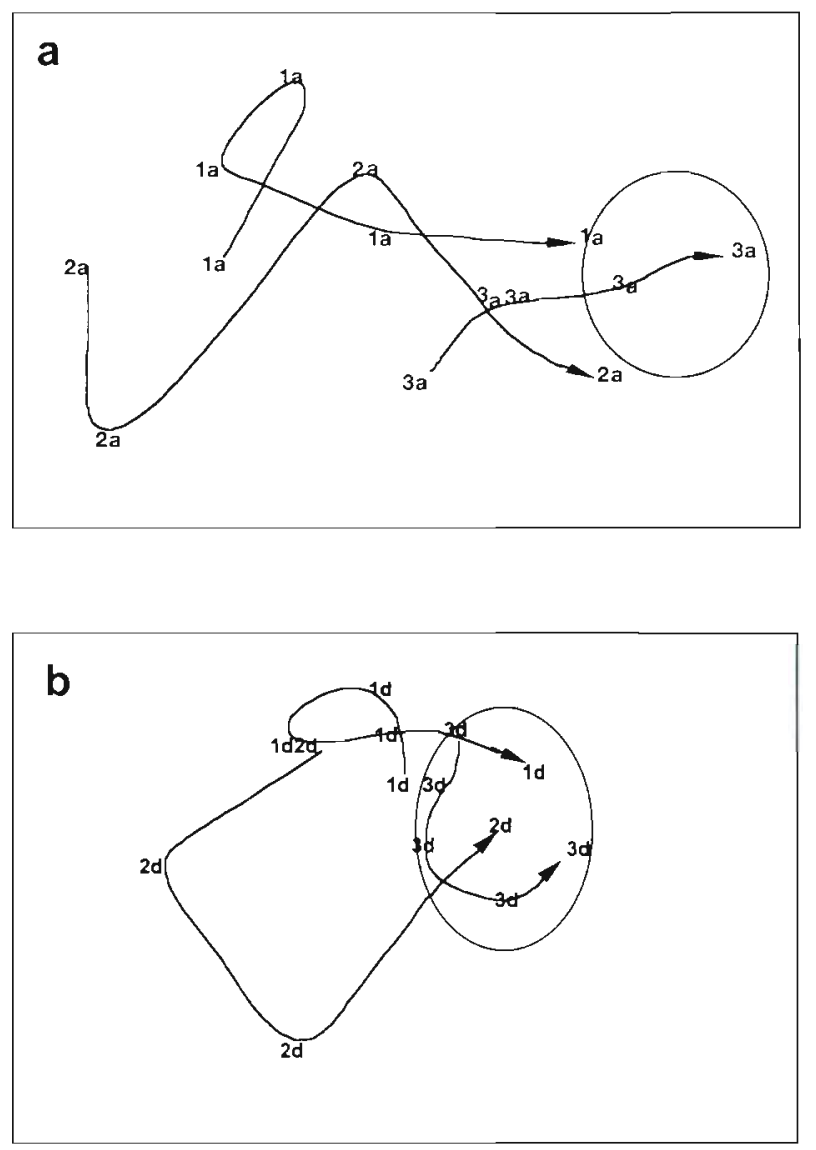

Fig. 6. (a) Recovery path for algal treatment in summer (stress $=0.16)$. Numbers indicate transplants and the circled area indicates where control samples are grouped. (b) Recovery path for defaunation treatment in summer (stress $=0.16$ ) Numbers indicate transplants and circled area indicates where control samples are grouped showed there was a $-20 \mathrm{~cm}$ diagonal slope across the site. Of the 38 ANOVA completed at the different times only 5 showed significant interaction effects. Of 40 ANOVA results, 2 on average will be incorrect, and only isolated significant differences with treatment were observed. Therefore, it was concluded that no
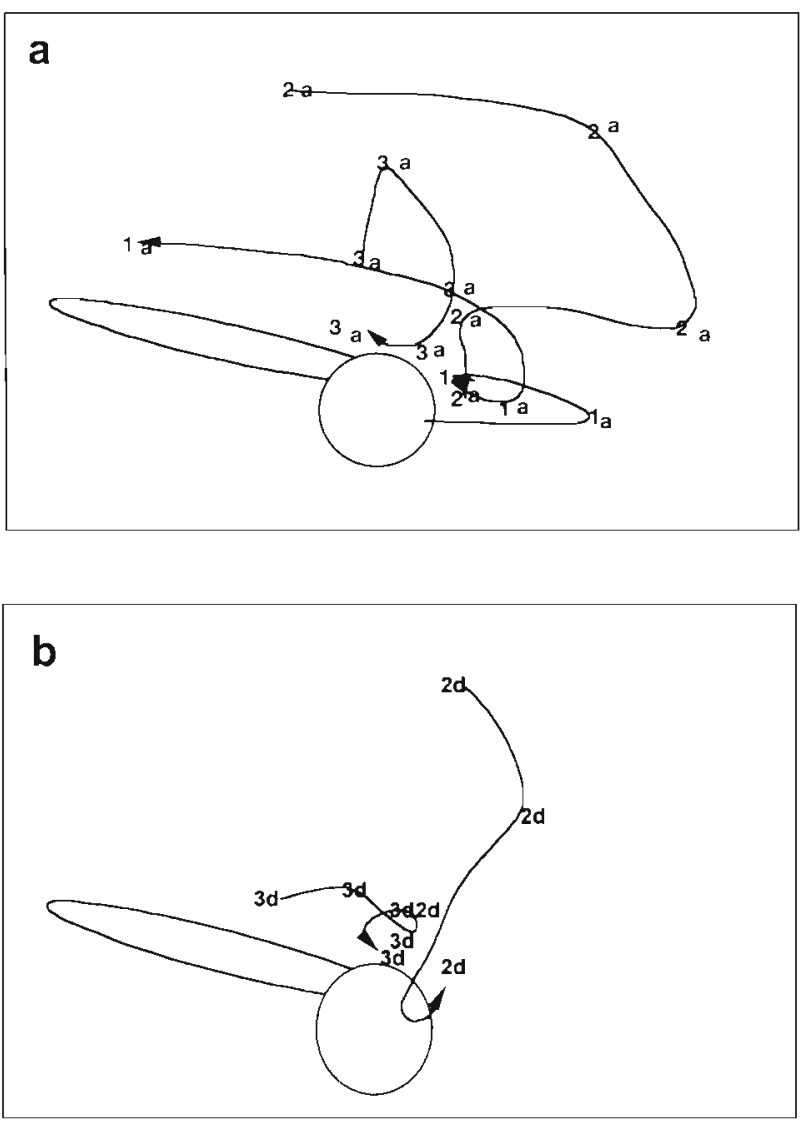

Fig. 7 (a) Recovery path for algal treatment in winter (stress $=0.17$ ). Numbers indicate transplants and the circled areas indicate where samples are grouped. (b) Recovery path for defaunation treatment in winter (stress $=0.17$ ). Numbers indicate transplants and the circled areas indicate where control samples are grouped, Transplant 1 lies completely within the control area 


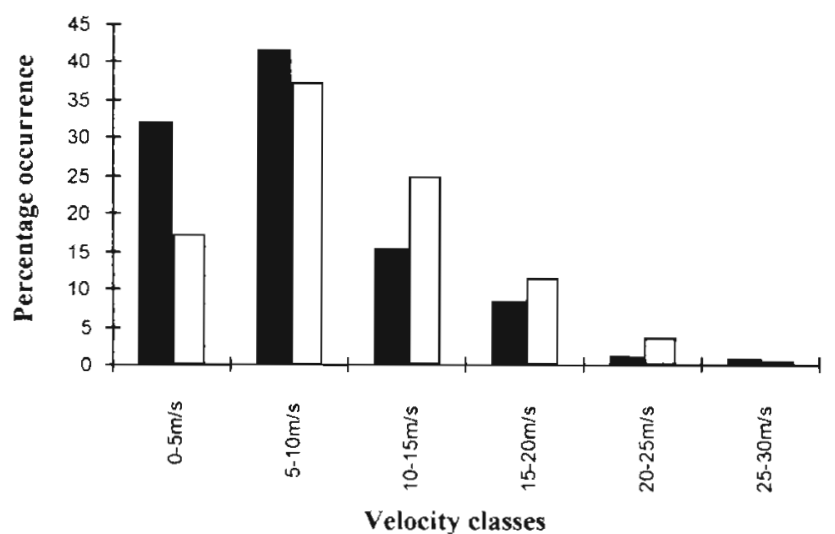

Fig. 8. Seasonal wind velocity comparison. (-) summer ${ }_{i}$ (ㅁ) winter

effect of treatment on bed height was present. As wind speed has been shown to affect bed height (Thrush et al. 1996), this relationship was tested. Averaging wind speed over the interval between consecutive sampling periods generated the wind factor. Change in bed height is poorly correlated with wind between sampling periods, the $\mathrm{R}^{2}$ values for winter and summer were 0.01 and 0.08 respectively. The relationship between wind and bed height was therefore considered unimportant.

\section{DISCUSSION}

Winter samples were characterised by more individuals and more species than those in summer. This difference is consistent with other studies that showed high variability between seasons (Lively et al. 1993, Turner et al. 1995). Densities of individuals within season increased through the summer and decreased through the winter (Fig. $2 \mathrm{a}-\mathrm{e}$ ). This trend suggests a peak density in late summer or autumn following summer reproduction, with declining densities until the next summer.

Experimental treatment effects upon colonisation, as gauged by multivariate analysis, were stıll signıficantly different on Day 50. This result provided little basis for comparison with similar studies however, as past researchers, e.g. Zajac \& Whitlatch $(1982 a, b)$, Thrush et al. (1996), used the less sensitive univariate analyses (Warwick \& Clarke 1991). Univariate indicators show that in summer and winter, number of individuals showed some recovery by Day 50 . Number of taxa, however, took $>50 \mathrm{~d}$ to recover in all but the summer defaunated treatment $(5$ to $>50 \mathrm{~d}$ ). Other small-scale disturbance recovery times have ranged from 1.8 to $40 \mathrm{~d}$ for most parameters (Smith \& Maclean 1977, Zajac \& Whitlatch 1982b, Bell \& Devlin 1983,
Levin 1984). This experiment shows similar times to other studies although the time to recovery of number of taxa is unknown. The exception to these studies was that of Thrush et al. (1996) in New Zealand, that took greater than 9 mo to recover. The explanation given for this anomalous result was that removal of the dominant Boccardia worm tubes destabilised the sandflat, leading to an erosion-prone sandflat that was, therefore, slow to recover.

The treatment effects seen for buried algal mats here are the first experimental evidence that they can significantly influence sandflat macrofauna. This confirms the observation that previously weeded areas can inhibit colonisation (Raffaelli et al. 1991). Even when surface algal mats, and therefore hydrodynamic 'baffling' effects, are not present, buried algae may decrease densities of corophiids in this and other coastal areas, thereby limiting corophiid repopulation when surface algal mats decline.

The order of relative dispersion values between treatments shows the level of variability decreased from $\mathrm{A}$ to $\mathrm{D}$ to $\mathrm{C}$ (Table 2). The addition of algae lowers oxygen levels and increases sulphide and toxic ammonium levels in the sediment (Hull 1987, Forster et al. 1996). Defaunation will also cause these effects through breakdown of frozen infauna (Valiela 1984, Chester 1996), but to a lesser extent because of the lower biomass involved. Intertidal amphipod distributions can be affected by oxygen concentrations, as can other macrofaunal distributions (Grant 1981, Agnew \& Taylor 1986). Therefore the dispersion changes between treatments are probably a result of infauna responding to the oxygen related stresses created by the defaunation and algal loading

Apparent RPD levels in the sediment in winter showed treatment effects that were variable with time (Table 3). These effects were concentrated at Days 25 and 50 of Transplants 1 (June) and 2 (July), indicating this is when the most degradation, and therefore oxygen use, occurred. These effects are consistent with the theory that algae are broken down to a useable state for amphipods in winter. Defaunation and algal treatments shared this effect, but only algal samples showed an increase in amphipods. This indicates the food resource was probably sufficient in algal samples to generate biostimulation (Chen \& Orlob 1972), but insufficient in defaunated samples. The absence of treatment effects at the end of Transplant 3 (August) may have been because the increased densities of amphipod burrows increased oxygen penetration in the sediment.

This is the first study to our knowledge that investigates seasonal differences in colonisation of algal mat disturbances. Seasonality in colonisation is important as algal mats can be present in or on the sediment 
throughout the year (Raffaelli et al. 1998). The same algal addition disturbance experiments in summer decreased and in winter increased the recovery times. This means that if algal mats stay at a site and undergo burial year round the effect on sandflat communities could range from negative to positive.

Seasonal differences in colonisation of algal treatments are probably due to differing oxygen availability with season. Oxygen has been recorded in fine sand to a depth of $18 \mathrm{~mm}$ (Andersen \& Helder 1987). Conceivably some of the decomposition of algae in Papanui Inlet could be by aerobic decomposition. Aerobic pathways of decomposition are faster and more efficient than anaerobic pathways (Aller 1994, Seibold \& Berger 1996). In summer, shallower oxygen penetration in sediments is expected due to the lower solubility of oxygen in water at higher temperatures (Rasmussen \& Jorgensen 1992). Higher wind speeds in winter may have caused more fluctuations in bed height, therefore the algae may have been closer to the sediment surface. Higher wind speeds in winter may have also caused greater oxygen penetration through wind-waves at the site (Riedl \& Machan 1972, Baillie 1986, Andersen \& Helder 1987, Brotas et al. 1990), therefore the algal layer may have been oxygenated more regularly. This claim is substantiated by the similarity in RPD depths between treatments in winter. Unfortunately no measurements were taken in summer, when RPD depths appeared to differ. In summer, therefore, more of the algae may have decomposed anaerobically, and the algal food source may not have been as readily available. Many amphipods are highly mobile and can increase opportunistically in response to increased food supply (Conlan 1994). Organic matter, therefore, probably decomposed to a useable state for deposit-feeding macrofauna faster in winter than summer (Van Blaricom 1982, Oliver \& Slattery 1985). The enrichment effect, of Paracorophium excavatum adults by algal treatments seen at Day 50 in winter (Fig. 5) was probably in response to this extra food resource.

Both rare and common species influenced colonisation rates at different temporal scales. Differences in colonisation rates between seasons were controlled by the diversity of taxa present. In winter, more rare taxa $\left(<1\right.$ individual core $\left.{ }^{-1}\right)$ were present in control sediments \& cores took $>50$ d to recover. More taxa were probably present in winter as individuals that settled in summer had by winter grown to a size able to be retained by our $0.5 \mathrm{~mm}$ sieve. In summer, less rare taxa were present \& colonisation was quicker. Colonisation was gauged to be slower in winter as the multivariate analysis gauges the importance of all species present in the community in assessing differences between samples. The absence of rare species in winter in disturbed cores therefore meant that winter samples were often classed as not recovered after $50 \mathrm{~d}$. The number of Paracorophium excavatum mainly controlled the speed of colonisation within season. The more $P$. excavatum present in a site the more quickly it recovered. This finding agrees with that of Zajac \& Whitlatch (1982a), where ambient population expansion in spring and summer also allowed high colonisation rates.

This is the first study of its kind to investigate colonisation within season, and it showed an unexpected result. Transplant 2 in winter (July) and summer (January) showed the most community effect (Figs. 6 \& 7). Number of individuals was the only factor that mimics the pattern of similarity between Transplant 2 in both seasons. Number of individuals was not significantly different for $W 2$ versus S2 and mean number of individuals was nearly identical for this pair of transplants (an average difference of $<4$ ), in comparison to all other pairs (Fig. 3). Both size classes of Paracorophium excavatum accounted for $>49 \%$ of all individuals at any time, and created this similarity between numbers of individuals. $P$. excavatum showed the same pattern of no significant difference between $\mathrm{S} 2$ versus $\mathrm{W} 2$, and the mean numbers of $P$. excavatum are again closest for this pair of transplants (an average difference of $<4$ ) in comparison to all other pairs. (Fig. 3). At this density of $P$. excavatum, approximately 20 per $8 \mathrm{~cm}$ diameter corer, the effects of defaunation, or defaunation and organic loading, were the most pronounced on $P$. excavatum, and subsequently the community. A possible explanation for this density being most susceptible to disturbance is that at densities lower than 20 per $8 \mathrm{~cm}$ diameter corer, relative effects could be expected because of lower numbers. At higher densities, the increased oxygen exchange from the bioturbation of $P$. excavatum may mitigate oxygen depletion, and therefore effect of disturbances. This suggests $P$. excavatum may be able to alter the attractiveness of the sediment by their bioturbation activities.

This result in Papanui Inlet shows, for the first time, that all common macrofaunal organisms can recolonise by post-settlement movement. This finding increases the importance of post-settlement movement of benthos in the colonisation of shallow-water disturbances (Thrush 1986, Gunther 1991, Commito et al. 1995a, Olivier et al. 1996, Shull 1997), although unlike Commito et al. (1995a) no seasonality in bedload movement was seen. This means colonisation on sandflats may not be influenced by whether the disturbance occurs in summer or winter.

The effect of wind on post-settlement movement and subsequently on colonisation, did not differ seasonally 
in this study. Wind speed has been shown to affect the amount of bedload transported, which is correlated with the amount of post-settlement movement (Emerson 1991, Commito et al. 1995b). Wind velocity differs seasonally in Papanui Inlet, therefore amount of bedload and post-settlement movement was expected to differ seasonally. Quantifying organisms moving in bedload transport is difficult. However, bedload traps indicated no changes in species composition of postsettlement movement. Therefore, wind affects colonisation rates seasonally only when the supply of recolonisers available to be transported differs seasonally, e.g. Beukema \& De Vlas (1989). Alternatively, wind may affect colonisation by the influence of windwaves in areas destabilised by disturbance (Thrush et al. 1996). Whether this destabilisation effect differs seasonally has yet to be tested. Availability of colonists and degree of exposure vary on a case-by-case basis. Consequently, the effects of wind driven waves on the bed and infauna may have to be investigated separately at each location. The influence of wind is unpredictable, even upon exposed sandflats, and will depend partially upon the available abundance of recolonisers.

In this paper we have shown that buried algal mats can have an impact on macrofaunal communities. This effect can differ between season and within season. In this sandflat the strongest community impact is linked to densities of the corophiid amphipod Paracorophium excavatum. A possible mechanism for the magnitude of community impact of disturbance on macrofauna is suggested which involves densities of $P$. excavatum that modify the ambient habitat by their burrowing activity. Therefore the impact of algal mats must be considered even when they are not present on the sediment surface, and these impacts may differ seasonally. This finding is intrinsically important because only when all the important factors involved in intertidal flats are documented, or quantified, can any overview or modelling of a system hope to have robustness over time. The affects documented here could also have important followon impacts in areas where amphipods are numerous as they are important prey items, and their colonisation of disturbance can be central to macrofaunal community dynamics in soft-sediment intertidal areas.

Acknowledgements. We are grateful to all the students and volunteers of the Portobello Marine Laboratory who aided in field and laboratory work, especially Craig Loveridge, who was called upon more than most. Scott Hagerthey and 3 reviewers improved this paper through their comments, we thank them. Lastly, thanks go to the National Institute of Water and Atmospheric Research Ltd (NIWA), which provided wind datd.

\section{LITERATURE CITED}

Agnew DJ, Taylor AC (1986) Effects of oxygen tension, temperature, salinity and humidity on the survival of two intertidal gammarid amphipods. Mar Ecol Prog Ser 32 $27-33$

Aller RC (1994) Bioturbation and remineralization of sedimentary organic matter: effects of redox oscillation. Chem Geol 114:331-345

Andersen FO, Helder W (1987) Comparison of oxygen microgradients, oxygen flux rates and electron transport system. activity in coastal marine sediments. Mar Ecol Prog Ser $37: 259-264$

Baillie PW (1986) Oxygenation of intertidal estuarine sediments by benthic microalagal photosynthesis. Estuar Coast Shelf Sci 22:143-149

Bell SS, Devlin DJ (1983) Short-term macrofaunal recolonisation of sediment and epibenthic habitats in Tampa Bay, Florida. Bull Mar Sci 33(1): 102-108

Bell RG, Hume TM. Dolphin TJ, Green MO, Walters RA (1997) Characterisation of physical environmental factors on an intertidal sandflat, Manukau harbour, New Zealand. J Exp Mar Biol Ecol 216:11-31

Beukema JJ (1973) Migration and secondary spatfall of Macoma balthica (L.) in the western part of the Wadden Sea Neth J Zool 23:356-357

Beukema JJ, De Vlas J (1989) Tidal-current transport of thread-drifting postlarval juveniles of the bivalve Macoma balthica from the Wadden Sea to the North Sea. Mar Ecol Prog Ser 52:193-200

Brotas V. Amorim-Ferriera A, Vale C. Catarino F (1990) Oxygen profiles in intertidal. sediments of Ria Formosa (S. Portugal). Hydrobiologia 207:123-129

Butman CA (1986) Sediment trap biases in turbulent flows: Results from a laboratory flume study. J Mar Res 44 : 645-693

Chen CW, Orlob GT (1972) The accumulation and significance of sludge in San Diego Bay. J Water Pollut Control Fed 44:1362-1371

Chester R (1996) Marine geochemistry. Chapman and Hall, London

Clarke KR (1993) Non-parametric multivariate analyses of changes in community structure. Aust J Ecol 18(1): $1.17-143$

Clarke KR, Green RH (1988) Statistical design and analysis for a 'biological effects' study. Mar Ecol Prog Ser 46 : $213-226$

Clarke KR, Warwick RM (1994) Change in Marine Communities: an approach to statistical analysis and interpretation. Natural Environment Research Council, United Kingdom

Commito JA, Currier CA, Reinsel KA, Ulm IM (1995a) Dispersal dynamics of the bivalve Gemma gemma in a patchy environment. Ecol Monogr 65(1):1-20

Commito JA, Thrush SF, Pridmore RD, Hewitt JE, Cummings VJ (1995b) Dispersal dynamics in a wind-driven benthic system. Limnol Oceanogr 40(8):1513-151.8

Conlan KE (1994) Amphipod crustaceans and environmental disturbance-a review. J Nat Hist 28(3):519-554

Cummings VJ, Pridmore RD, Thrush SF, Hewitt JE (1993) Emergence and floating behaviours of post-settlement juveniles of Macomona Liliana (Bivalvia Tellinacea). Mar Behav Physiol 24:25-32

Diaz-Castenada V, Frontier S, Arenas V (1993) ExperimentaI Re-establishment of a soft bottom community: Utilization. of Multivariate Analyses to characterize different benthic recruitments. Estuar Coast Shelf Sci 37:387-402

Emerson CW (1991) A method for measurement of bedload 
sediment transport and passive faunal transport on intertidal sandflats. Estuaries 14:361-371

Field JG, Clarke KR, Warwick RM (1982) A practical strategy for analysing multispecies distribution patterns. Mar Ecol Prog Ser 8:37-52

Forster S, Huettel M, Ziebis W (1996) Impact of boundary layer flow velocity on oxygen utilisation in coastal sediments. Mar Ecol Prog Ser 143:173-185

Frid CLJ (1989) The role of recolonization processes in benthic communities, with special reference to the interpretation of predator-induced effects. J Exp Mar Biol Ecol 126: $163-171$

GESAMP IMO/FAO/UNESCO/WMO/WHO/IAEA/UN/UNEP Joint Group of Experts on the Scientific Aspects of Marine Pollution) (1990) The state of the marine environment. GESAMP Reports and Studies 39

Grant A, Tyler PA (1983) The analysis of data in studies of invertebrate reproduction. II. The analysis of oocyte size/frequency data, and comparison of different types of data. Int J Inverteb Reprod 6:271-283

Grant J (1981) Factors affecting the occurrence of intertidal amphipods in reducing sediments. J Exp Mar Biol Ecol 49: $203-216$

Grant J (1985) A method for measuring horizontal transport of Organic Carbon over Sediment. Can J Fish Aquat Sci 42: 595-602

Gunther CP (1991) Settlement of Macoma balthica on an intertidal sandflat in the Wadden Sea. Mar Ecol Prog Ser $76: 73-79$

Gunther CP (1992) Dispersal of invertebrates: a strategy to react to disturbances of different scales. Neth J Sea Res 30: $45-56$

Haberman SJ (1973) The analysis of residuals in a cross classified table. Biometrics 28:205-220

Holm S (1979) A simple sequentially rejective multiple test procedure. Scand J Stat 6:65-70

Hull SC (1987) Macroalgal mats and species abundance: a field experiment. Estuar Coast Shelf Sci 25(5):519-532

Johnson RG (1973) Conceptual models of benthic marine communities. Models in paleobiology. Freeman, Cooper and Co, California, p 149-159

Lambshead PJD, Gooday AJ (1990) The impact of seasonally deposited phytodetritus on epifaunal and shallow infaunal benthic foraminiferal populations in the bathyl northeast Atlantic: the assemblage response. Deep-Sea Res 37 : 1263-1283

Lambshead PJD, Hodda M (1994) The impact of disturbance on measurements of variability in marine nematode populations. Vie Milieu 44:21-27

Levin LA (1984) Life history and dispersal patterns in a dense polychaete assemblage: community structure and response to disturbance. Ecology 65(4):1185-1200

Lincoln RJ (1979) British Marine Amphipoda. In: Clay R (ed) Gammaridea B. M. o. N history. The Chaucer Press Ltd, Bungay

Lively CM, Ramandi PT, Delph LY (1993) Intertidal community structure: space-tıme interactions in the northern gulf of California. Ecology 74(1):162-173

Nicholls DJ, Tubbs CR, Hayes FN (1981) The effect of green algal mats on intertidal macrobenthic communities and their predators. Kiel Neeresforsch 5:511-520

Norkko A (1997) The role of drifting macroalgal mats in structuring coastal zoobenthos. PhD thesis, Huso Biological Station, Åbo Akademi University

Norkko A, Bonsdorff E (1996) Altered benthic prey-availability due to episodic oxygen deficiency caused by drifting algal mats. Mar Ecol (Napoli) 17(1-3):355-372
Oliver JS, Slattery PN (1985) Destruction and opportunity on the seafloor; Effects of gray whale feeding. Ecology 66 : $1965-1975$

Olivier FC, Vallet J, Dauvin C, Retiere C (1996) Drifting in post-larvae and juveniles in an abra alba (wood) community of the eastern part of the bay of Seine (English channel). J Exp Mar Biol Ecol 199(1):89-109

Pearson TH, Stanley SO (1979) Comparative measurements of the redox potential of marine sediments as a rapid means of assessing the effect of organic pollution. Mar Biol 53:371-379

Peterson $\mathrm{CH}$, Irlandi EA, Black $\mathrm{R}$ (1994) The crash in suspension-feeding bivalve populations (Katelysia spp.) in Princess Royal Harbour: an unexpected consequence of eutrophication. J Exp Mar Biol Ecol 176:39-52

Raffaelli D, Hull S, Milne $H$ (1989) Long-term changes in nutrients, weed mats and shorebirds in an estuarine system. Cah Biol Mar 30(2):259-270

Raffaelli D, Limia J, Hull S, Pont S (1991) Interactions between the amphipod Corophium volutator and the macroalgal mats on estuarine mudflats. J Mar Biol Assoc UK 71:809-908

Raffaelli D, Raven J, Poole L (1998) Ecological impact of green macroalgal blooms. Oceanogr Mar Biol Annu Rev 36: $97-125$

Rasmussen $H_{1}$ Jorgensen BB (1992) Microelectrode studies of seasonal oxygen uptake in a coastal sediment: role of molecular diffusion. Mar Ecol Prog Ser 81(3):289-303

Rice WR (1989) Analyzing tables of statistical tests. Evolution 43(1):223-225

Riedl RJ, Machan R (1972) Hydrodynamic patterns in lotic intertidal sands and their bioclimatological implications. Mar Biol 13:179-209

Santos SL, Simon JL (1980) Marine soft bottom community establishment following annual defaunation: larval or adult recruitment? Mar Ecol Prog Ser 2:235-241

Seibold E, Berger WH (1996) The seafloor: an introduction to marine geology. Springer, Berlin

Shoemaker CR (1934) The amphipod genus Corophium volutator on the east coast of America. Proc Biol Soc Wash 47 : $23-32$

Shull DH (1997) Mechanisms of infaunal polychaete dispersal and colonization in an intertidal sandflat. J Mar Res 55: $153-179$

Smith CR, Brumsickle SJ (1989) The effects of patch size and substrate isolation on colonization modes and rates in an intertidal sediment. Limnol Oceanogr 34(7):1263-1277

Smith JD, McLean SR (1977) Spatially averaged flow over a wavy surface. J Geophys Res 82:1735-1746

Sousa WP (1984) The role of disturbance in natural communities. Annu Rev Ecol Syst 15:353-391

Thrush SF (1986) The sublittoral macrobenthic community structure of an Irish sea-Lough: effect of decomposing accumulations of seaweed. J Exp Mar Biol Ecol 96: 199-212

Thrush SF, Roper DS (1988) Merits of macrofaunal colonization of intertidal mudflats for pollution monitoring-preliminary studies. J Exp Mar Biol Ecol 116(3):219-233

Thrush SF, Whitlatch RB, Pridmore RD, Hewitt JE, Cummings VJ, WIlkinson MR (1996) Scale-dependant recolonization: the role of sediment stability in a dynamic sandflat habitat. Ecology 77(8):2472-2487

Tufail A, Meadows PS, McLaughlin P (1989) Meso- and microscale heterogeneity in benthic community structure and the sedimentary environment on an intertidal muddysand beach. Sci Mar (Barc) 53:319-327

Turner SJ, Thrush SF, Pridmore RD, Hewitt JE, Cummings VJ, Maskery M (1995) Are soft-sediment communities 
stable? An example from a windy harbour. Mar Ecol Prog Ser 120:219-230

Valiela I (1984) Marine ecological processes. Springer-Verlag, New York

Van Blaricom GR (1982) Experimental analyses of the structural regulation in a marine sand community exposed to oceanic swell. Ecolog Monogr 52:283-305

Warwick RM, Clarke KR (1991) A comparison of methods for analysing changes in benthic community structure. J Mar Biol Assoc UK 71:225-244

Warwick RM, Clarke KR (1993) Increased variability as a

Editorial responsibility: John Gray (Contributing Editor). Oslo, Norway symptom of stress in marine communities. J Exp Mar Biol Ecol 172:215-226

Wilson WH (1989) Predation and mediation of intraspecific competition in an infaunal community in the Bay of Fundy. J Exp Mar Biol Ecol 132(3):221-245

Zajac RN, Whitlatch RB (1982a) Responses of estuarine infauna to disturbance. I. Spatial and temporal variation of initial recolonization. Mar Ecol Prog Ser 10:1-14

Zajac RN, Whitlatch RB (1982b) Response of estuarine infauna to disturbance. II. Spatial and temporal variation of succession. Mar Ecol Prog Ser 10:15-27

Submitted: May 16, 1999; Accepted: August 2, 1999 Proofs received from author(s): December 21, 1999 